Bài báo khoa hoc

\title{
Phân tị́ch và đánh giá quá trình xói lở và bồi tụ ở khu vực Cà Mau bằng ảnh viễn thám và GIS \\ Nguyễn Tiến Thành ${ }^{1}$
}

\author{
${ }^{1}$ Khoa Vật lý-Vật lý Kỹ thuật, Trường Đại học Khoa học Tự nhiên, ĐHQG-HCM; \\ ntthanh@hcmus.edu.vn \\ * Tác giả liên hệ: ntthanh@hcmus.edu.vn; Tel.: +84-345095349
}

Tóm tắt: Rút trích dữ liệu đường bờ bằng việc sử dụng công nghệ viễn thám và GIS là việc cần thiết để đánh giá sự thay đổi đường bờ một cách nhanh chóng và kịp thời. Cà Mau là khu vực có 3 mặt giáp biển nên ở đây luôn xảy ra quá trình xói lở và bồi tụ diễn ra một cách mạnh mẽ. Nghiên cứu đã sử dụng ảnh viễn thám và GIS để thành lập bản đồ biến động đường bờ ở khu vực Cà Mau. Kết quả cho thấy, đường bờ ở khu vực Cà Mau diễn biến khá phức tạp. Cụ thể, khu vực phía Đông Cà Mau từ Đầm Dơi tới Ngọc Hiển hầu hết chỉ xảy ra quá trình xói lở từ 1989-2017, tuy nhiên ở khu vực gần mũi Cà Mau thì lại xảy ra quá trình bồi tụ, còn ở khu vực phía Tây Cà Mau từ mũi Cà Mau đến Huyện U Minh thì quá trình bồi tụ lại chiếm ưu thế trong giai đoạn 1989-2015 nhưng ở giai đoạn từ 2015-2017 thì quá trình xói lở. Đây là một trong những thông tin hữu ích cho các cơ quan chức năng của địa phương để có những giải pháp quy hoạch và quản lý vùng ven bờ.

Từ khóa: Rút trích đường bờ; GIS; Xói lở; bồi tụ; Cà Mau.

\section{Mở đầu}

Cà Mau là tỉnh duy nhất của nước ta có 3 mặt giáp biển với chiều dài bờ biển $254 \mathrm{~km}$ là nơi có rừng ngập mặn phân bố, phát triển mạnh. Ngoài ra Cà Mau còn là nơi nằm giữa 2 luồng hải lưu của biển Đông và của vịnh Rạch Giá nên ở đây có hiện tượng xói lở và bồi tụ diễn ra rất phức tạp [1]. Do đó, quan trắc diển biến sự thay đổi đường bờ khu vực Cà Mau là cần thiết cho công tác quản lý bền vững đường bờ ở khu vực này.

Trên thế giới đã có rất nhiều nghiên cứu sử dụng dữ liệu ảnh viễn thám để phân loại nước đất từ ảnh về tinh đa thời gian, sau đó chồng xếp để nhận dạng và đánh giá biến động đường bờ [2]. Cụ thể, [3] đã thành lập bản đồ hiện trạng rừng ngập mặn ở Nam Á và xác định sự thay đổi độ che phủ rừng ngập mặn (tăng và giảm) từ năm 2000 đến năm 2012 bằng dữ liệu vệ tinh Landsat. [4] đã thực hiện phân loại và lập bản đồ thực vật rừng ngập mặn cũng như tỷ lệ xói mòn và bồi tụ dọc theo bờ biển Bhitarkanika, bờ biển phía Đông của Ấn Độ bằng cách sử dụng dữ liệu vệ tinh Landsat 7 và 8 từ năm 1989 đến năm 2013. [5] đã sử dụng ảnh Landsat từ bốn thời đại 1976 (Landsat MSS) 1989 (Landsat TM) 2000 (Landsat ETM+) và 2015 (Landsat $L 8 O L I$ ) để định lượng chính xác mức độ và mật độ rừng ngập mặn thay đổi/biến thiên trong khu vực nghiên cứu.

Bên cạnh đó, đã có rất nhiều nghiên cứu về biến động đường bờ được thực hiện ở Việt Nam trong những năm gần đây. Cụ thể, [6] đã sử dụng viễn thám kết hợp hệ thống phân tích đường bờ kĩ thuật số (Digital Shoreline Analysis System-DSAS), để nghiên cứu sự thay đổi rừng ngập mặn ở vùng Giao Thủy của tỉnh Nam Định. [7] đã ứng dụng viễn thám kết hợp với GIS để nghiên cứu biến động đường bờ tại Kiên Giang và sử dụng mô hình để dự báo xu thế diễn biến đường bờ tại Rạch Giá (Kiên Giang). [8] đã sử dụng các hình ảnh trên không (1953), Landsat $(1979,1988$ và 2000$)$ và $\operatorname{SPOT}(1992,1995,2004,2008,2009$ và 2011$)$ và hệ thống phân tích bờ biển (Digital Shoreline Analysis System-DSAS) để định lượng tỷ lệ 
thay đổi bờ biển ngập mặn trong thời gian 58 năm. [9] đã thu thập các bản đồ hiện trạng rừng, bản đồ diễn biến đường bờ biển và điều tra ngoại nghiệp ở khu vực rừng phòng hộ ven biển tỉnh Bạc Liêu. Nhìn chung, phương pháp viễn thám cho thấy hiệu quả trong công việc giám sát biến động đường bờ. Mục tiêu của nghiên cứu này là đánh giá mức độ biến động đường bờ ở khu vực tỉnh Cà Mau bằng ảnh Lansat và kết hợp với ArcGIS để tính toán được tốc độ xói lở bờ khu vực Cà Mau.

\section{Phương pháp nghiên cứu}

\subsection{Khu vục nghiên cứu}

Dựa vào tình trạng biến động đường bờ ở khu vực biển Đông và Tây Cà Mau từ năm 1989 đến 2017 được chia làm 5 vùng nhỏ từ phải sang trái và được đánh dấu từ 1 đến 5 của Hình 1. Vùng 1 từ Đầm Dơi đến xã Nguyễn Huân (Cà Mau) cách cửa Bồ Đề $8 \mathrm{~km}$. Vùng 2 là khu vực cửa Bồ Đề. Vùng 3 là đoạn bờ từ xã Tân An cách cửa Bồ Đề $16 \mathrm{~km}$ đến đông mũi Cà Mau. Vùng 4 là phần mũi Cà Mau và hai cửa sông: Ông Trang, Bảy Hạp. Vùng 5 là đoạn bờ từ huyện Cái Nước đến huyện U Minh.

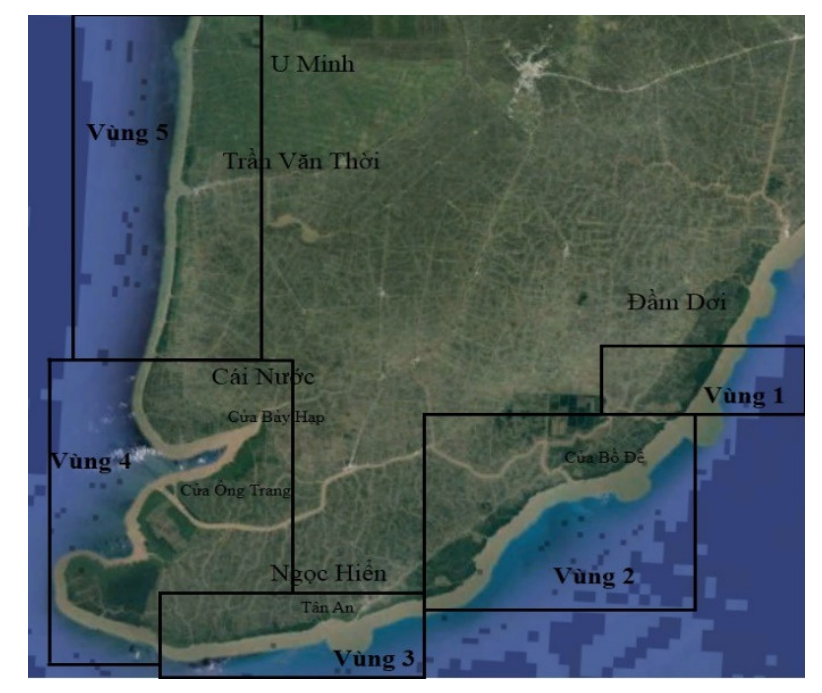

Hình 1. Phân vùng khu vực Cà Mau.

\subsection{Quy trìh thục hiện}

Dữ liệu ảnh vệ tinh Landsat thu thập được: ở phía đông của khu vực Cà Mau vào năm 1989, 1998, 2000, 2004, 2008, 2015, ở phía tây Cà Mau vào năm 1989, 1998, 2001, 2004, 2008, 2010, 2015, 2017 (trên website EarthExplore của Cơ quan Địa chất Hoa Kỳ (USGS): http://www.glovis.usgs.gov). Nghiên cứu sử dụng công cụ ENVI 4.7 để xử lý ảnh viễn thám qua các bước: Hiệu chỉnh hình học, nhằm loại bỏ những sai lệch xảy ra trong quá trình chụp ảnh và đưa ảnh về tọa độ chuẩn có thể tích hợp với các nguồn dữ liệu khác. Chuyển đổi dạng số sang giá trị phản xạ phổ, để giảm sự khác biệt giá trị phản xạ phổ của đối tượng ở các loại sensor khác nhau và giảm sự khác biệt giữa các ảnh khác nhau. Xử dụng công cụ Band Math để tạo ra ảnh có các chỉ số tách biệt giữa đất và nước và cuối cùng là rút trích đường bờ. 


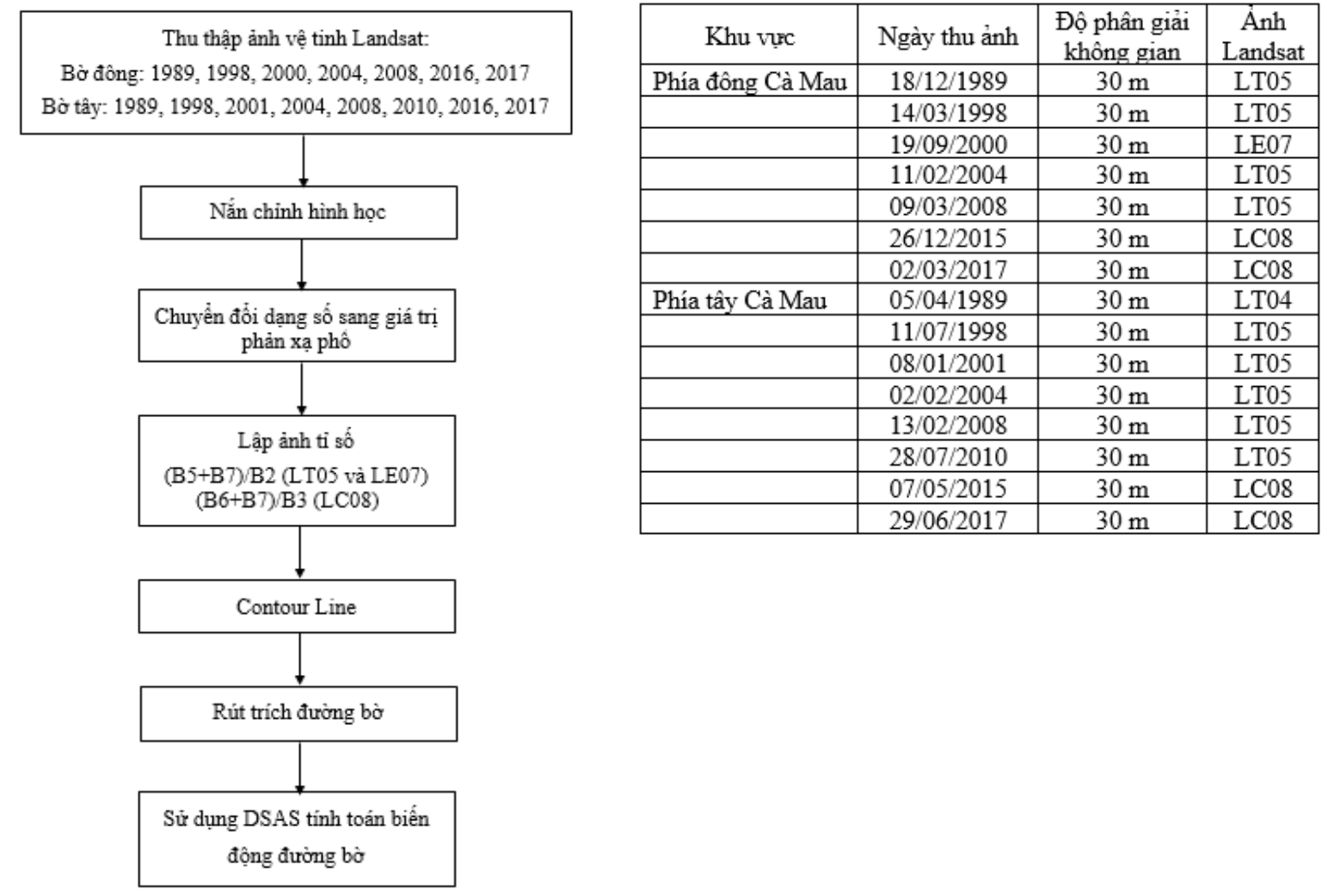

Hình 2. Quy trình thực hiện và dữ liệu ảnh viễn thám.

\subsection{Sủ dụng DSAS trong ArcGIS để tính toán biến động đương bò̀}

Sau khi rút trích đường bờ của các ảnh viễn thám ở khu vực biển đông và biển tây Cà Mau ta sẽ đánh giá được biến động đường bờ ở khu vực đó. Tuy nhiên đánh giá biến động đường bờ chỉ mang tính khách quan không định lượng một cách rõ ràng. Để có thể đánh giá sự biến động đường bờ một cách định lượng ta cần phải sử dụng công cụ DSAS (Digital Shoreline Analysis System-Hệ thống phân tích đường bờ kỹ thuật số) giúp cho người sử dụng có thể tính toán được mức độ thay đổi đường bờ theo thời gian dựa vào vị trí phức tạp của đường bờ [10]. Để vận hành được công cụ DSAS này đầu tiên phải tạo ra 2 thuộc tính là đường bờ (Shorelines) và đường gốc (Baseline) trong đó đường bờ (Shorelines) là nơi chứa các đường bờ đã được chọn ra từ viễn thám còn đường gốc (Baseline) là đường được tạo ra do người sử dựg thiết lập với mục đích là tạo ra các đường trực giao (Transect) từ đường gốc (Baseline) cắt qua các đường bờ (Shorelines) từ đó ta có thể tính được khoảng cách từ các đường bờ (Shorelines) đến đường gốc (Baseline) và đường (Baseline) ở đây được chọn là một đường thẳng song song với các đường (Shorelines). Từ đó tính toán được mức độ thay đổi đường bờ qua các năm.

\section{Kết quả và thảo luận}

\subsection{Biến động đường bò̀ vùng 1}

Vùng 1 là đoạn bờ từ Đầm Dơi đến xã Nguyễn Huân trong các năm từ 2008 đến 2015 đường bờ lại có xu hướng xói lở, trung bình xói lở đạt khoảng $16 \mathrm{~m} / \mathrm{năm}$, còn ở giai đoạn 2015 đến 2017 cũng xảy ra quá trình xói lở nhưng mức độ thấp hơn khoảng $8 \mathrm{~m} /$ năm (Hình $3)$. 


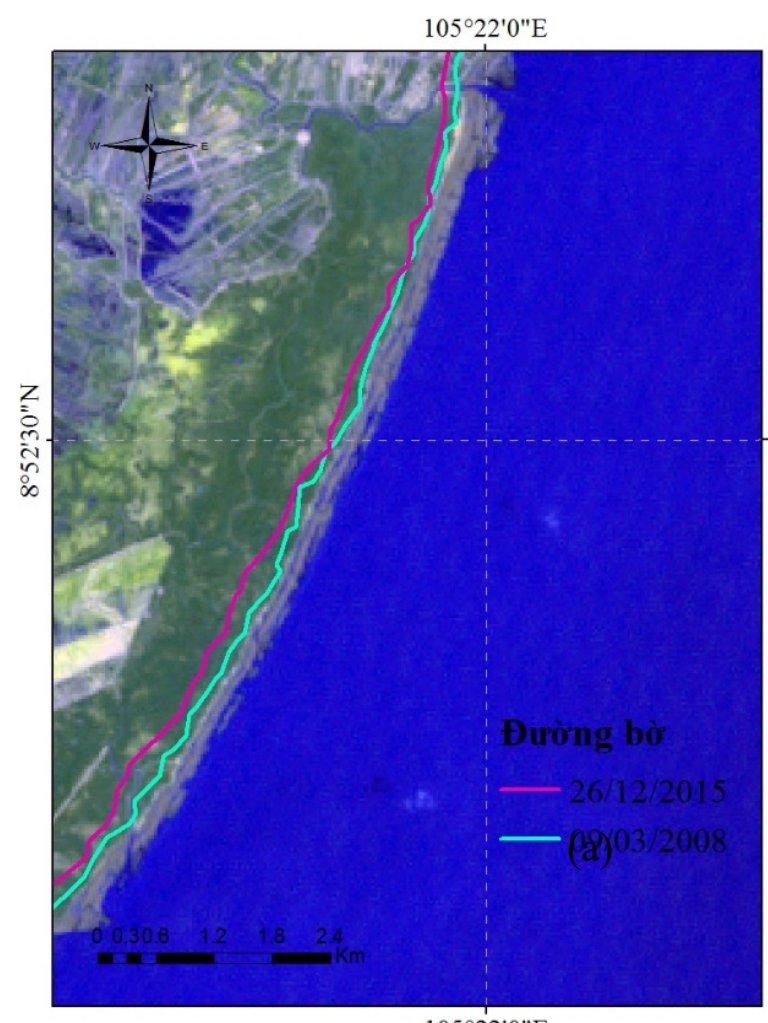

$105^{\circ} 22^{\prime} 0^{\prime \prime} \mathrm{E}$

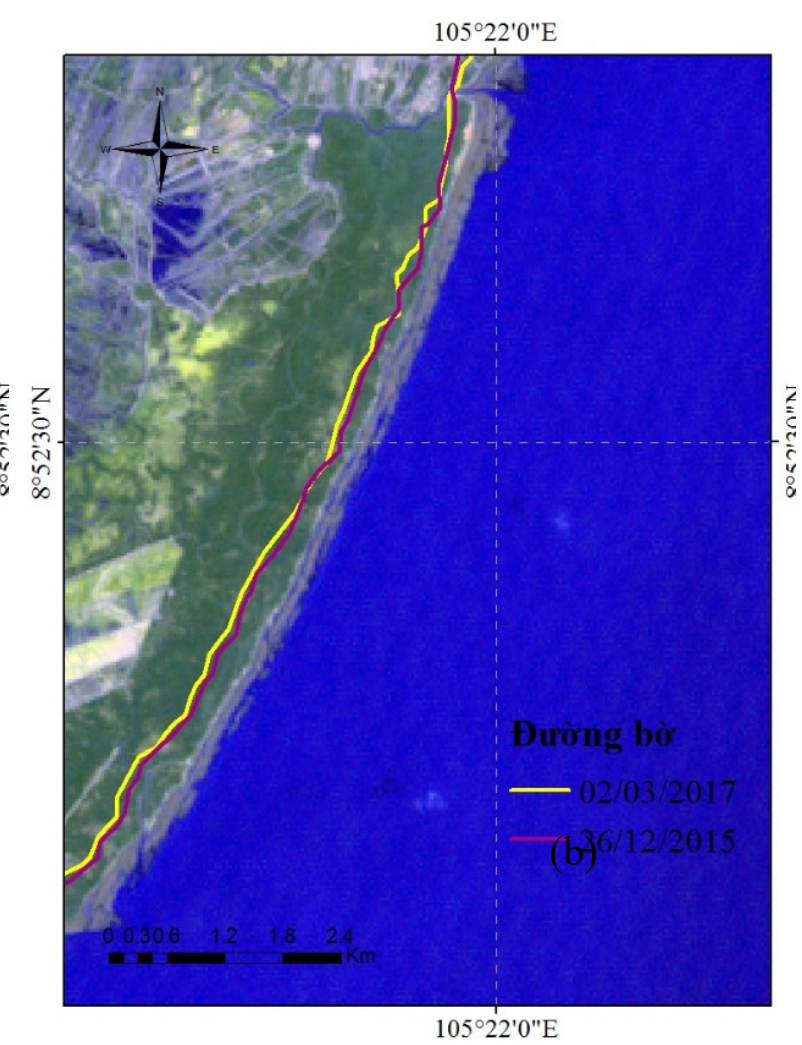

Hình 3. Biến động đường bờ vùng 1: (a) 2008-2015, (b) 2015-2017.

\subsection{Biến động đường bờ vùng 2}

Vùng 2 nằm trong khu vực cửa Bồ Đề qua các năm từ 1989, 1998, 2000, 2004, 2008, 2015, 2017 cũng tương tự như vùng 1 là quá trình xói lở chiếm ưu thế, tuy nhiên mức độ xói lở lớn hơn. Cụ thể, ở vùng 2 năm 1989 đến 1998 (Hình 4a) quá trình xói lở chiểm ưu thế, trung bình đạt khoảng 25 m/năm, từ năm 1998 đến 2000 (Hình 4b), hầu hết cũng chỉ có quá trình xói lở xảy ra, trung bình xói lở đạt khoảng 30 m/năm lớn hơn nhiều so với khu vực 1 .

Từ năm 2000 đến 2004 (Hình 5a) ta thấy xói lở cũng chiếm ưu trong giai đoạn này, trung bình đạt $32 \mathrm{~m} /$ năm, từ năm 2004 đến 2008 (Hình 5b) nhìn chung đường bờ có xu hướng ổn định và ít thay đổi hơn so với các giai đoạn 1989 đến 1998, 19989 đến 2000 và 2000 đến 2004, trung bình xói lở đạt khoảng 16 m/năm.

Từ năm 2008 đến 2015 (Hình 6a) quá trình xói lở cũng chiếm ưu thế và mức độ lớn hơn so với giai đoạn 2004 đến 2008, trung bình đạt khoảng $30 \mathrm{~m} /$ năm và từ giai đoạn 2015 đến 2017 (Hình 6b) quá trình xói lở cũng chiếm ưu thế, nhưng mức độ xói lở thấp hơn giai đoạn 2008 đến 2015, trung bình xói lở đạt khoảng 20 m/năm. 


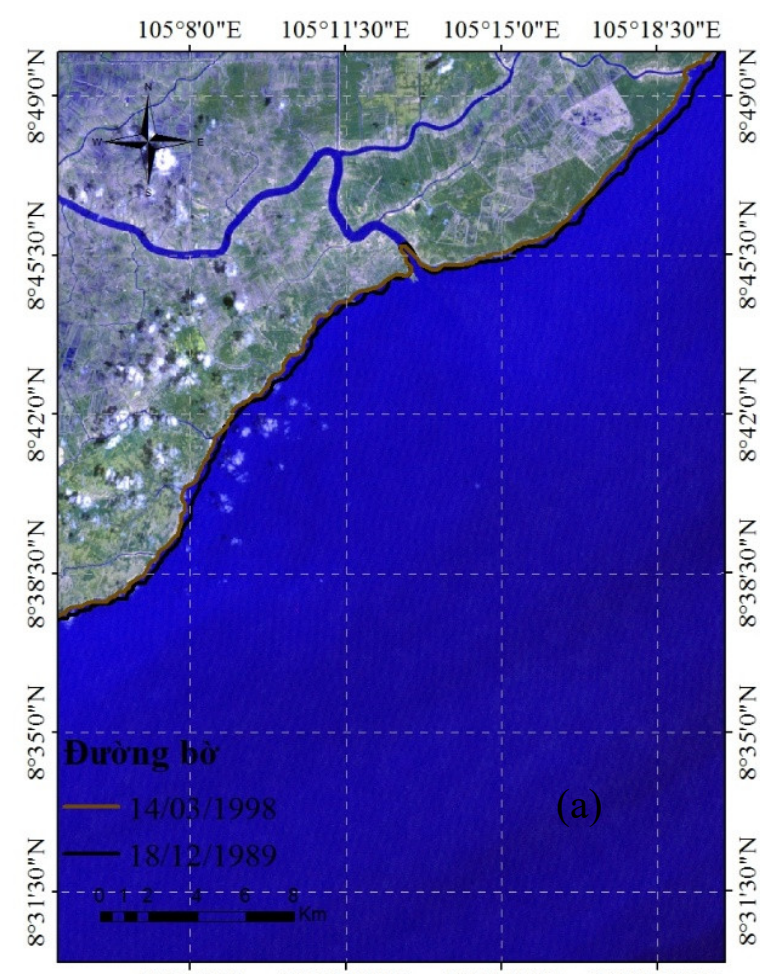

$105^{\circ} 8^{\prime} 0^{\prime \prime} \mathrm{E} \quad 105^{\circ} 11^{\prime} 30^{\prime \prime} \mathrm{E} \quad 105^{\circ} 15^{\prime} 0{ }^{\prime \prime} \mathrm{E} \quad 105^{\circ} 18^{\prime} 30^{\prime \prime} \mathrm{E}$

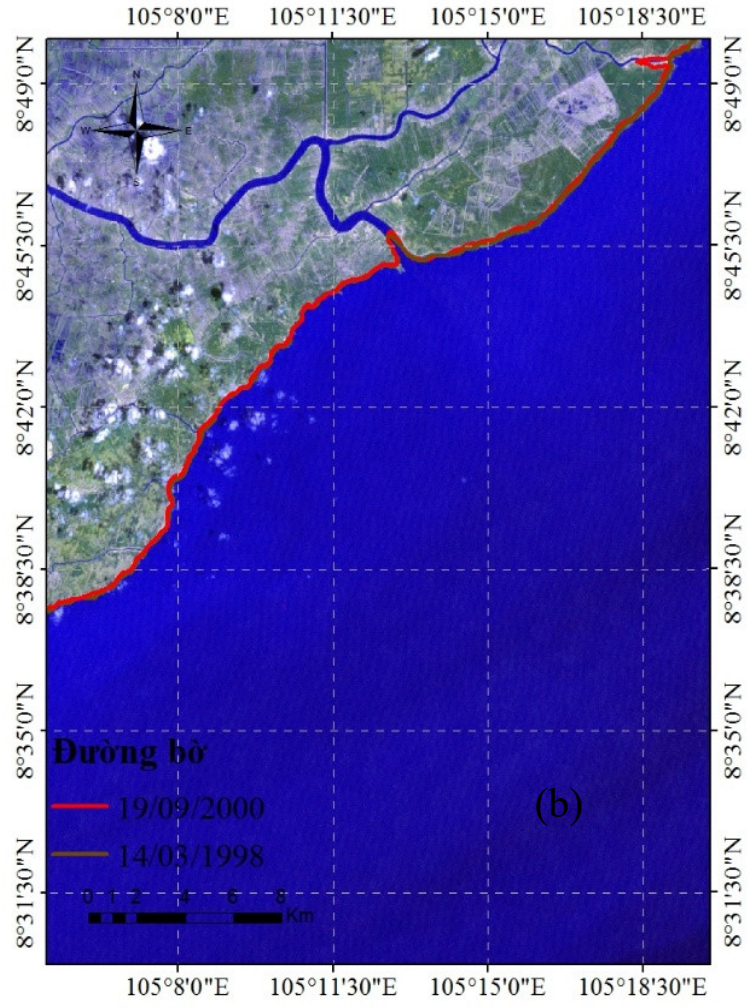

$105^{\circ} 8^{\prime} 0^{\prime \prime} \mathrm{E} \quad 105^{\circ} 11^{\prime} 30^{\prime \prime} \mathrm{E} \quad 105^{\circ} 15^{\prime} 0^{\prime \prime} \mathrm{E} \quad 15^{\circ} 18^{\prime} 30^{\prime \prime} \mathrm{E}$

Hình 4. Biến động đường bờ vùng 2: (a) 1989-1998; (b) 1998-2000.
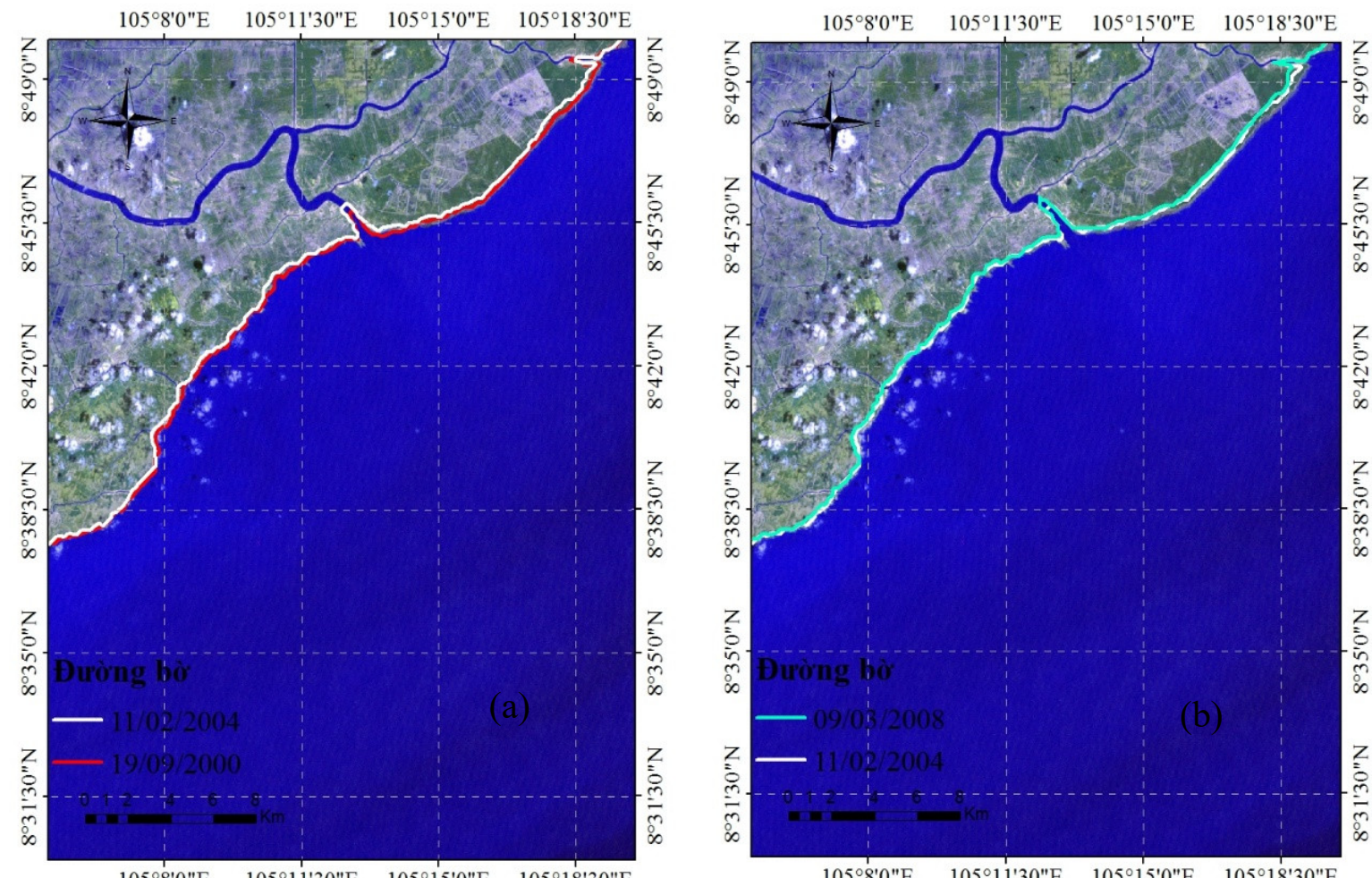

$105^{\circ} 8^{\prime} 0^{\prime \prime} \mathrm{E} \quad 105^{\circ} 11^{\prime} 30^{\prime \prime} \mathrm{E} \quad 105^{\circ} 15^{\prime} 0^{\prime \prime} \mathrm{E} \quad 105^{\circ} 18^{\prime} 30^{\prime \prime} \mathrm{E}$

$105^{\circ} 8^{\prime} 0 " \mathrm{E} \quad 105^{\circ} 11^{\prime} 30^{\prime \prime} \mathrm{E} \quad 105^{\circ} 15^{\prime} 0^{\prime \prime} \mathrm{E} \quad 105^{\circ} 18^{\prime} 30^{\prime \prime} \mathrm{E}$

Hình 5. Biến động đường bờ vùng 2: (a) 2000-2004; (b) 2004-2008. 

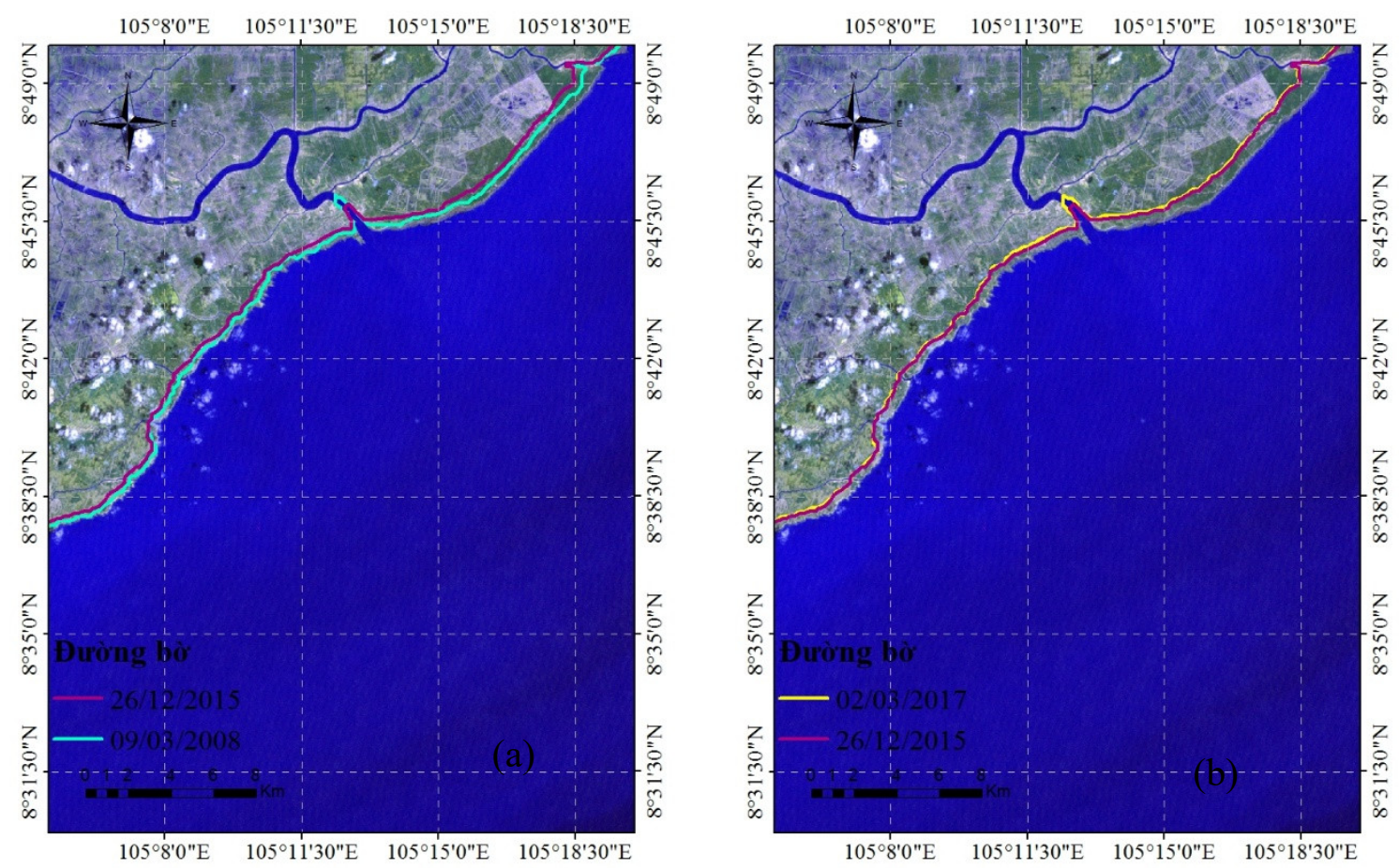

Hình 6. Biến động đường bờ vùng 2: (a) 2008-2015; (b) 2015-2017.

\subsection{Biến động đường bờ vùng 3}

Vùng 3 là đoạn bờ từ xã Tân An cách cửa Bồ Đề $16 \mathrm{~km}$ đến đông mũi Cà Mau qua các năm từ 1989, 1998, 2000, 2004, 2008, 2015, 2017 cũng tương tự như vùng 1 và 2 là quá trình xói lở chiếm ưu thế và mức độ xói lở thấp hơn so với vùng 2.

Cụ thể, giai đoạn từ 1989 đến 1998 (Hình 7a) ta thấy hầu hết xảy ra quá trình xói lở, trung bình đạt $16 \mathrm{~m} / \mathrm{năm}$, tuy nhiên ở khu vực phía mũi Cà Mau lại có xu hướng bồi tụ trung bình khoảng 14 m/năm. Giai đoạn từ 1998 đến 2000 (Hình $7 b$ ) cũng xảy ra quá trình xói lở, nhưng mức độ lớn hơn giai đoạn 1989 đến 1998 đạt khoảng 20 m/năm và cũng có xu hướng bồi tụ ở khu vực phía mũi Cà Mau, trung bình đạt khoảng 14 m/năm.

Giai đoạn 2000 đến 2004 (Hình 8a) nhìn chung ta cũng thấy quá trình xói lở chiếm ưu thế, tuy nhiên mức độ lại thấp hơn so với 2 giai đoạn trước đó là 1989 đến 1998 và 1998 đến 2000, trung bình xói lở đạt khoảng $10 \mathrm{~m} /$ năm, tuy nhiên ở khu vực phái mũi Cà Mau quá trình bồi tụ lại xảy ra nhiều hơn, trung bình đạt khoảng 22 m/năm. Ở giai đoạn 2004 đến 2008 (Hình $8 \mathrm{~b}$ ) đường bờ có xu hướng ổn định hơn so với các giai đoạn trước, mức độ xói lở trung bình đạt $7 \mathrm{~m} / \mathrm{năm}$, còn ở khu vực phía mũi Cà Mau bồi tụ xảy ra rất mạnh khoảng $38 \mathrm{~m} / \mathrm{năm}$.

Giai đoạn 2008 đến 2015 (Hình 9a) quá trình xói lở cũng chiếm ưu thế hơn và có xu hướng tăng lên so với giai đoạn 2004 đến 2008, trung bình xói lở đạt khoảng 14 m/năm, còn ở khu vực phía mũi Cà Mau, quá trình bồi tụ có xu hướng giảm đi so với giai đoạn 2004 đến 2008 đạt khoảng $14 \mathrm{~m} /$ năm. Còn ở giai đoạn 2015 đến 2017 cũng tương tự như các giai đoạn trên là quá trình xói lở cũng chiếm ưu thế đạt khoảng $16 \mathrm{~m} / \mathrm{năm}$, tuy nhiên ở khu vực phía mũi Cà Mau quá trình bội tụ giảm rất nhiều chỉ còn khoảng $4 \mathrm{~m} / \mathrm{năm}$. 


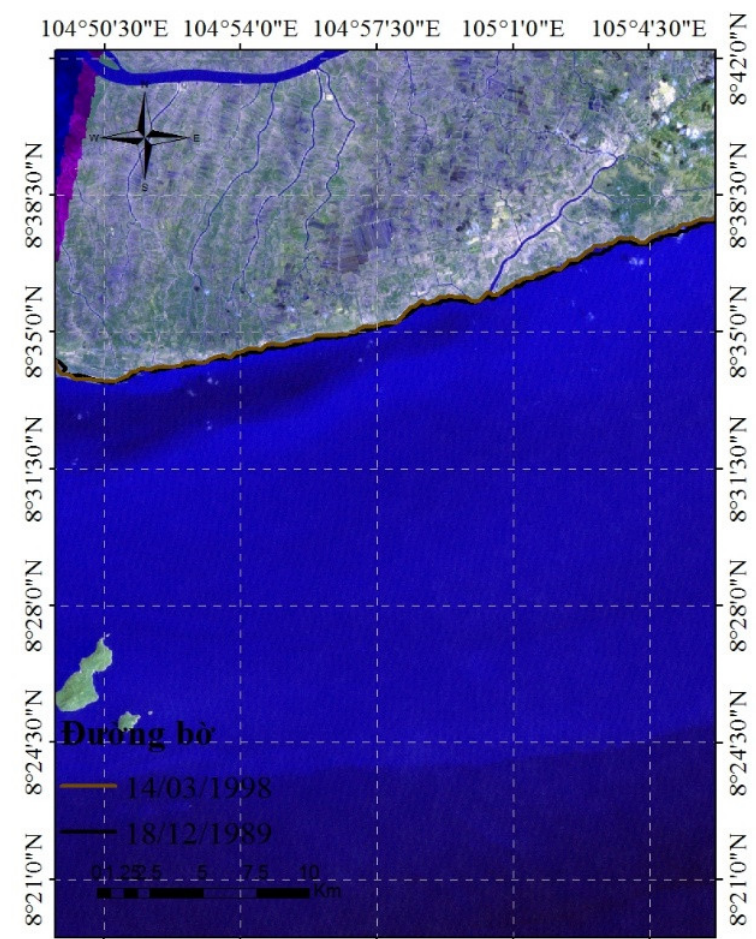

$104^{\circ} 50^{\prime} 30^{\prime \prime E} \quad 104^{\circ} 54^{\prime} 0^{\prime \prime E} \quad 104^{\circ} 57^{\prime} 30^{\prime \prime} \mathrm{E} \quad 105^{\circ} 1^{\prime} 0 " \mathrm{E} \quad 105^{\circ} 4^{\prime} 30^{\prime \prime E}$

(a)

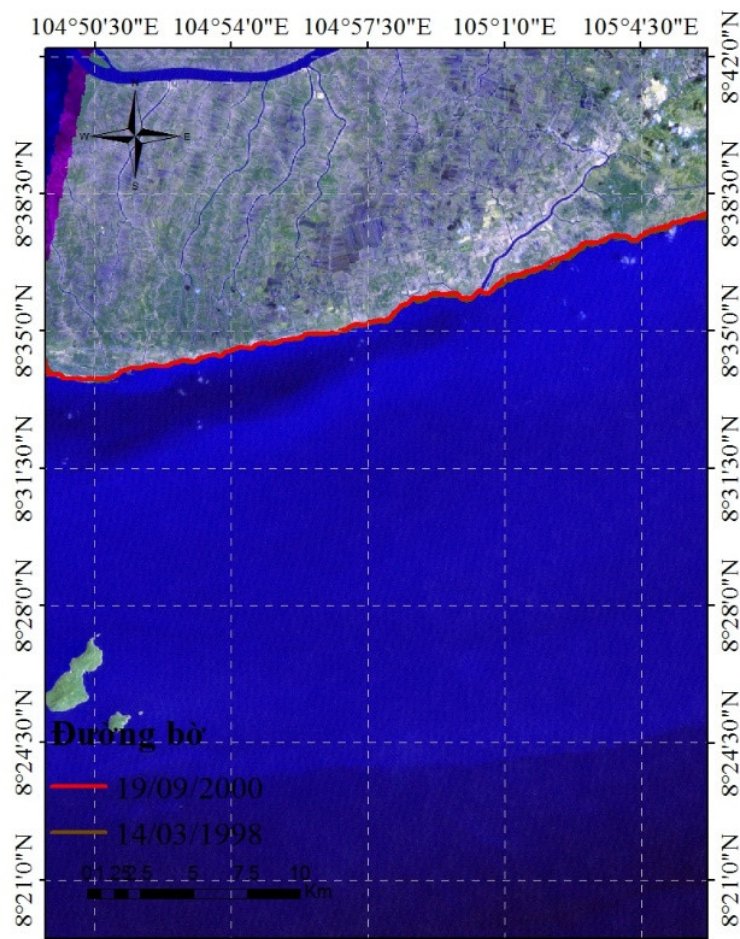

(b)

Hình 7. Biến động đường bờ vùng 3: (a) 1989-1998; (b) 1998-2000.

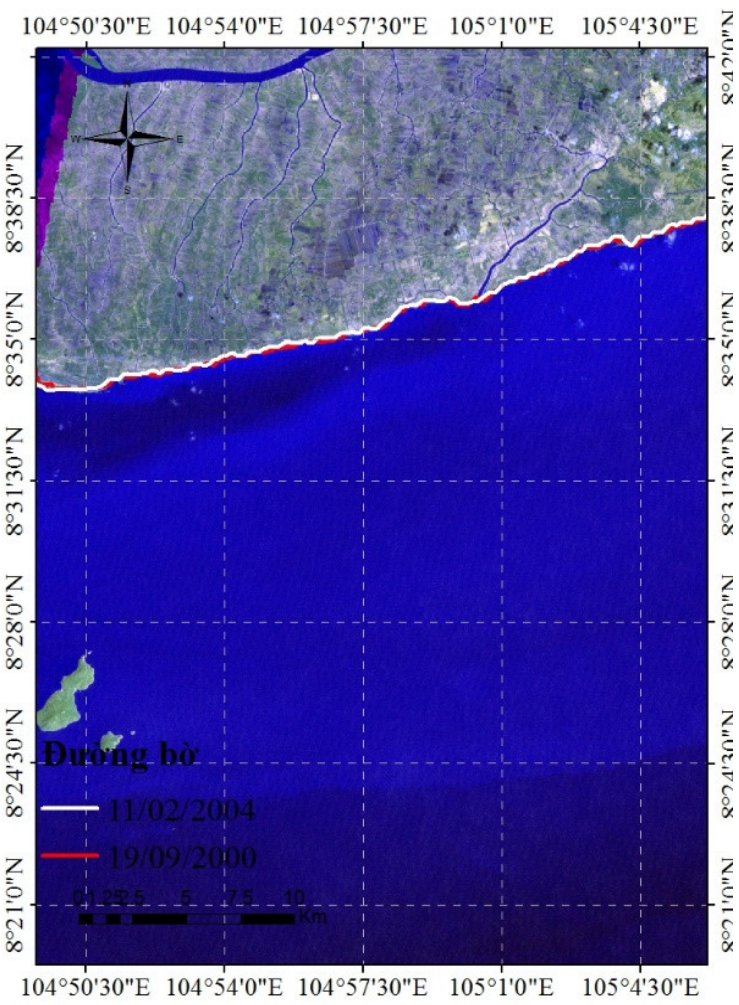

(a)

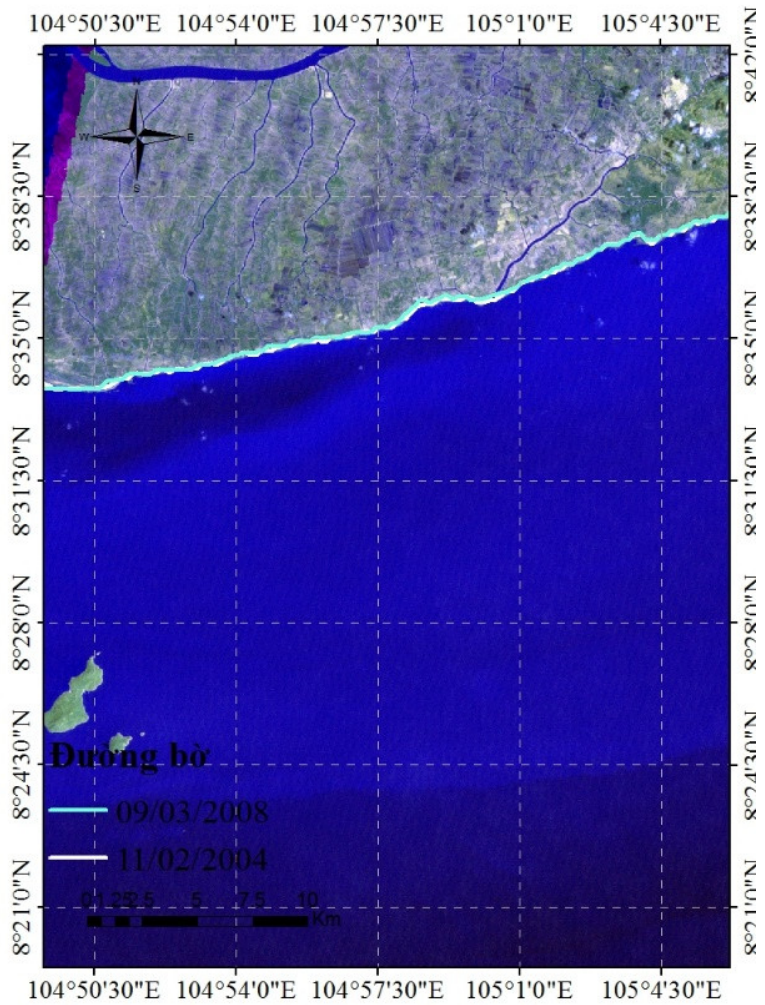

(b)

Hình 8. Biến động đường bờ vùng 3: (a) 2000-2004; (b) 2004-2008. 


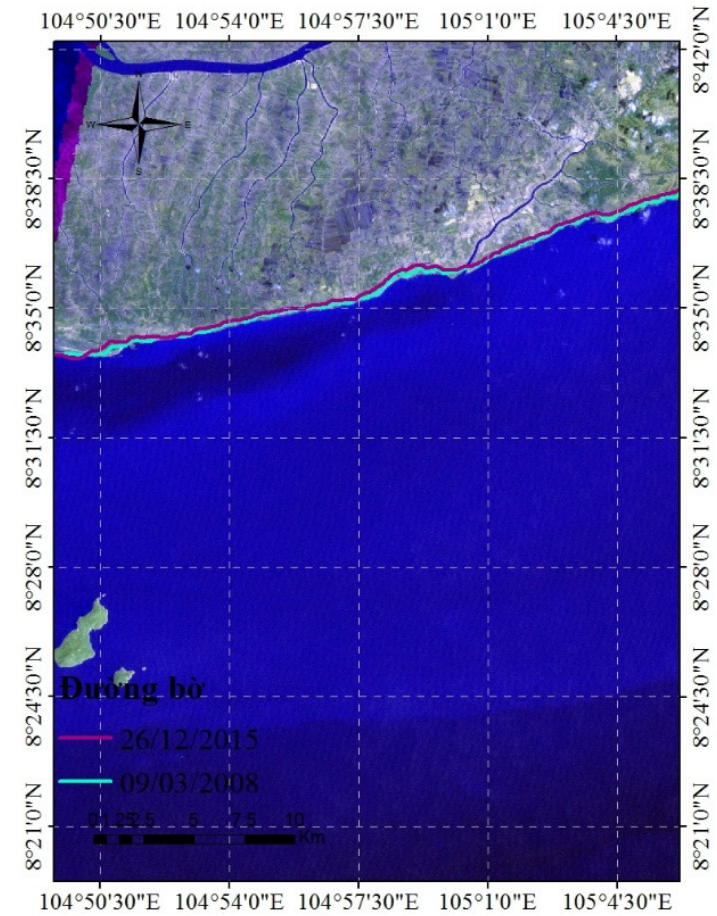

(a)

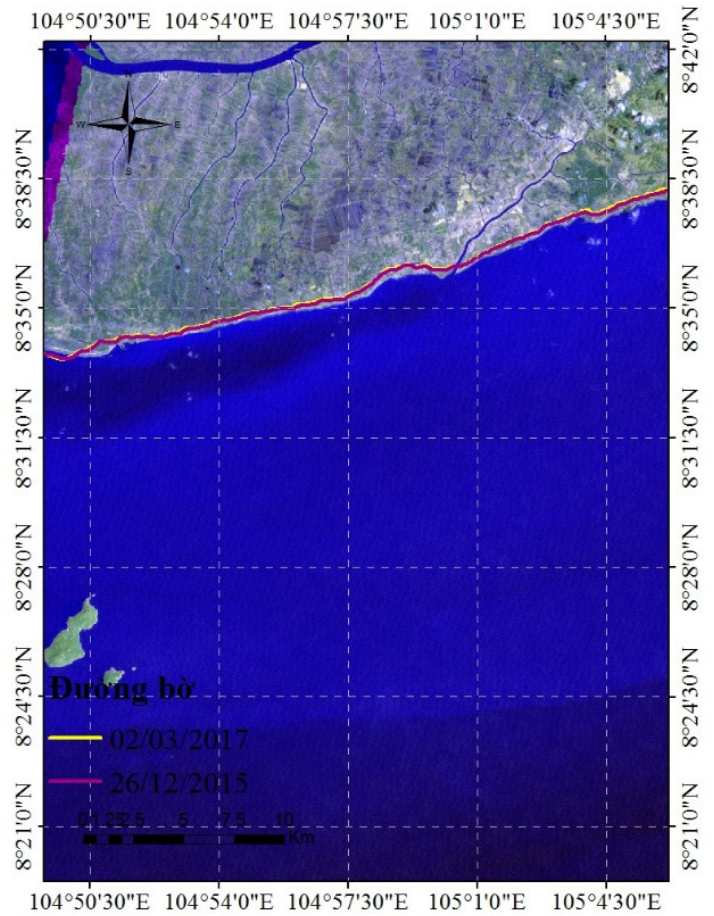

(b)

Hình 9. Biến động đường bờ vùng 3: (a) 2008-2015; (b) 2015-2017.

\subsection{Biến động đường bò̀ vùng 4}

Vùng 4 là đoạn bờ biển Tây Cà Mau có 2 cửa sông lớn là Ông Trang và Bảy Hạp, được biểu diễn ở Hình 10, 11, 12 và 13 qua các năm từ 1989-2017. Từ năm 1989-2015 từ mũi Cà Mau đến cửa Bảy Hạp được bồi tụ liên tục với cường độ khá mạnh, tuy nhiên ở khu vực mũi đông Cà mau thì lại có xu hướng xói lở. Ngoài ra quá trình bồi tụ mạnh tập trung chủ yếu ở 2 khu vực cửa sông lớn là Ông Trang và Bảy Hạp hơn phía ngoài bờ biển. Cụ thể, ta chia là 2 khu vực là phía mũi đông Cà Mau và phía tây Cà Mau.

Ở phía mũi đông Cà Mau, trong giai đoạn từ năm 1989-1998 xảy ra quá trình xói lở, với mức độ đạt khoảng 65 m/năm (Hình 10a). Giai đoạn từ 1998-2004 thì lại có xu thế bồi, với mức độ trung bình đạt $40 \mathrm{~m} /$ năm (Hình $10 \mathrm{~b}$ và $11 \mathrm{a}$ ). Giai đoạn 2004-2010 thì quá trình xói lở lại chiếm ưu thế trung bình khoảng $60 \mathrm{~m} /$ năm (Hình $11 \mathrm{~b}$ và $12 \mathrm{a}$ ). Giai đoạn $2010-2015$ thì lại có xu hướng ngược lại so với giai đoạn 2004-2010 là quá trình bồi tụ chiếm ưu thế đạt trung bình khoảng 30 m/năm (Hình 12b), tuy nhiên ở giai đoạn 2015-2017 thì lại xảy ra quá trình xói lở trung bình khoảng 24 m/năm (Hình 13).

Ở khu vực phía tây Cà Mau, hầu hết các giai đoạn từ năm 1989-2015 đều xảy ra quá trình bồi tụ và mạnh nhất ở giai đoạn 1998-2004, tuy nhiên ở giai đoạn năm 2015-2017 thì quá trình xói lở lại chiếm ưu thế hơn. Cụ thể, giai đoạn năm 1989-1998 quá trình bội tự đạt khoảng trung bình $27 \mathrm{~m} /$ năm (Hình 10a), giai đoạn 1998-2004 bồi tụ đạt trung bình khoảng $86 \mathrm{~m} /$ năm (Hình $10 \mathrm{~b}$ và $11 \mathrm{a}$ ), ở các giai đoạn 2004-2010 (Hình $11 \mathrm{~b}$ và $12 \mathrm{a}$ ), 2010-2015 (Hình 12b) thì lại xảy ra quá trình xói lở và bồi tụ, tuy nhiên quá trình bồi tụ vẫn chiếm ưu thế hơn đạt trung bình khoảng $3 \mathrm{~m} / \mathrm{năm}$, tuy nhiên ở giai đoạn 2015-2017 thì quá trình xói lở lại chiếm ưu thế hơn đạt trung bình khoảng 10 m/năm. 


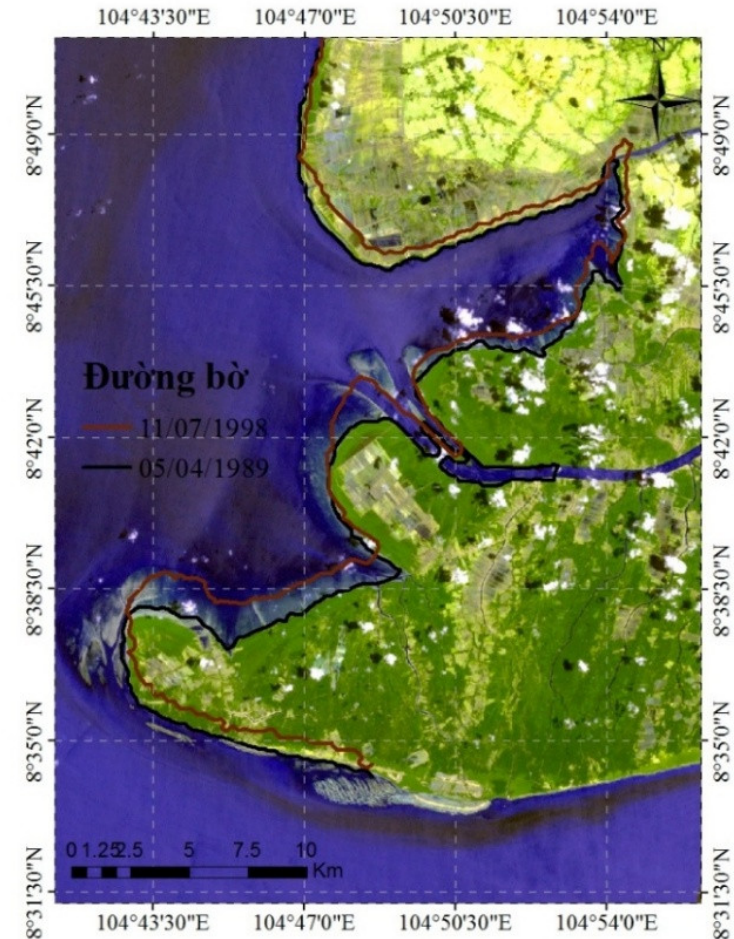

(a)

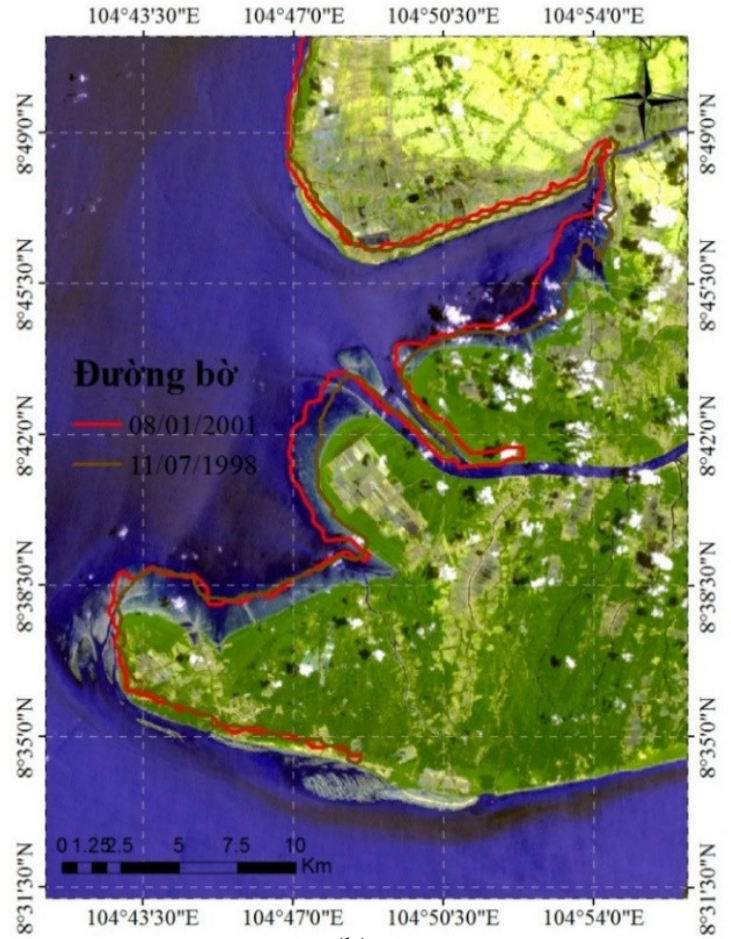

(b)

Hình 10. Biến động đường bờ vùng 4: (a) 1989-1998; (b) 1998-2001.

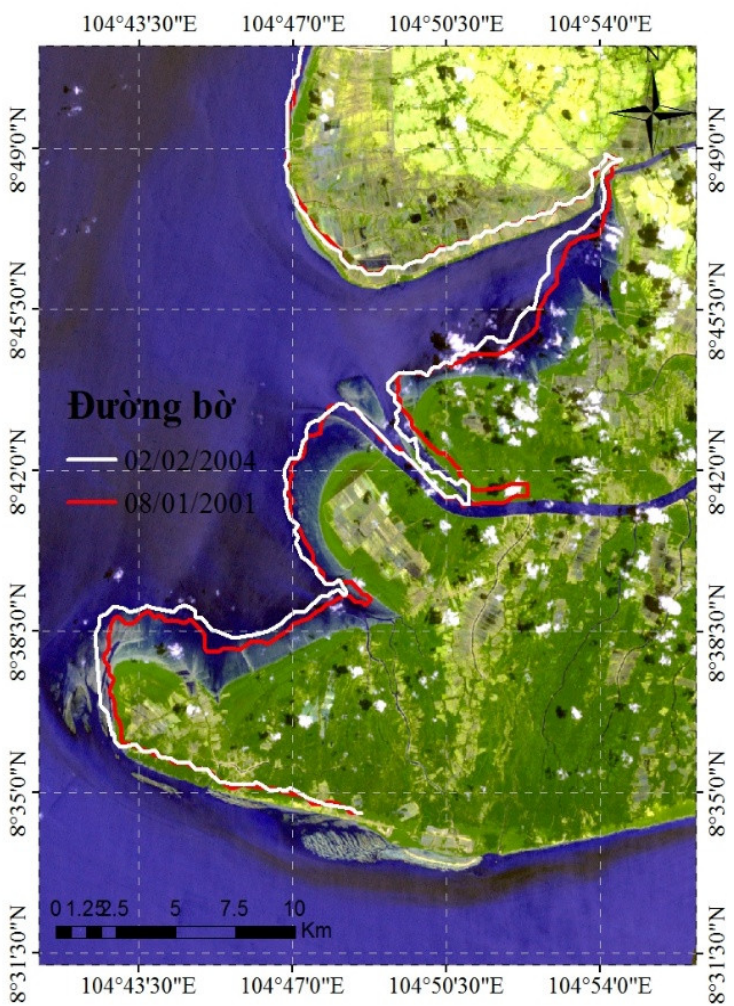

(a)

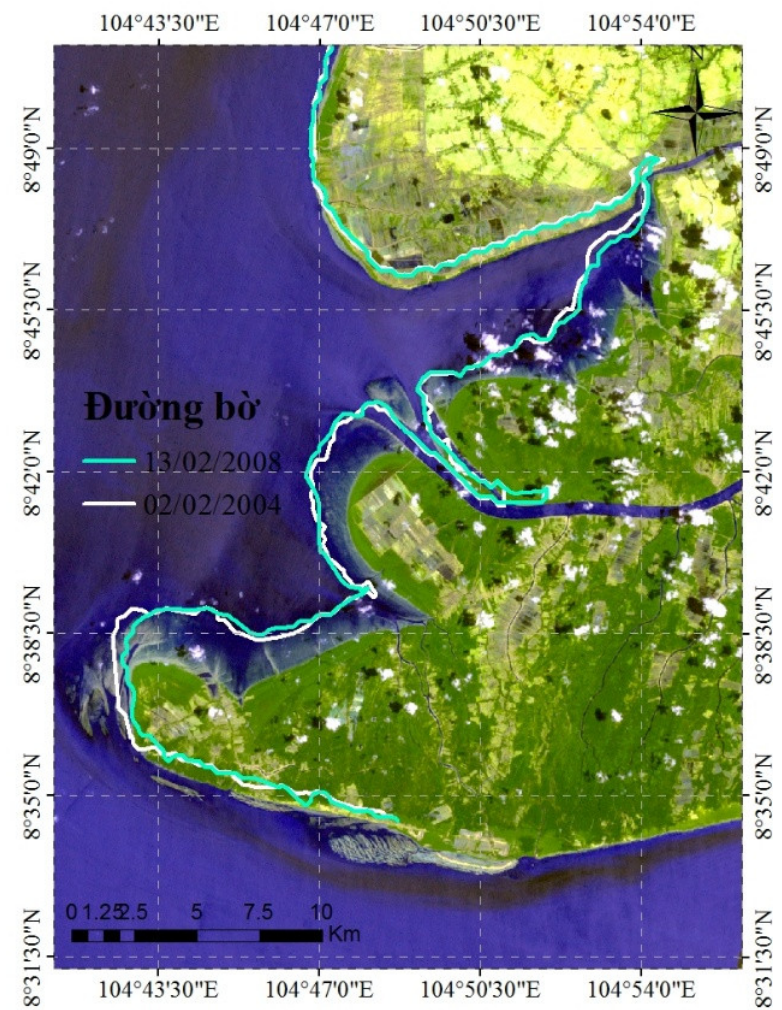

(b)

Hình 11. Biến động đường bờ vùng 4: (a) 2001-2004; (b) 2004-2008. 


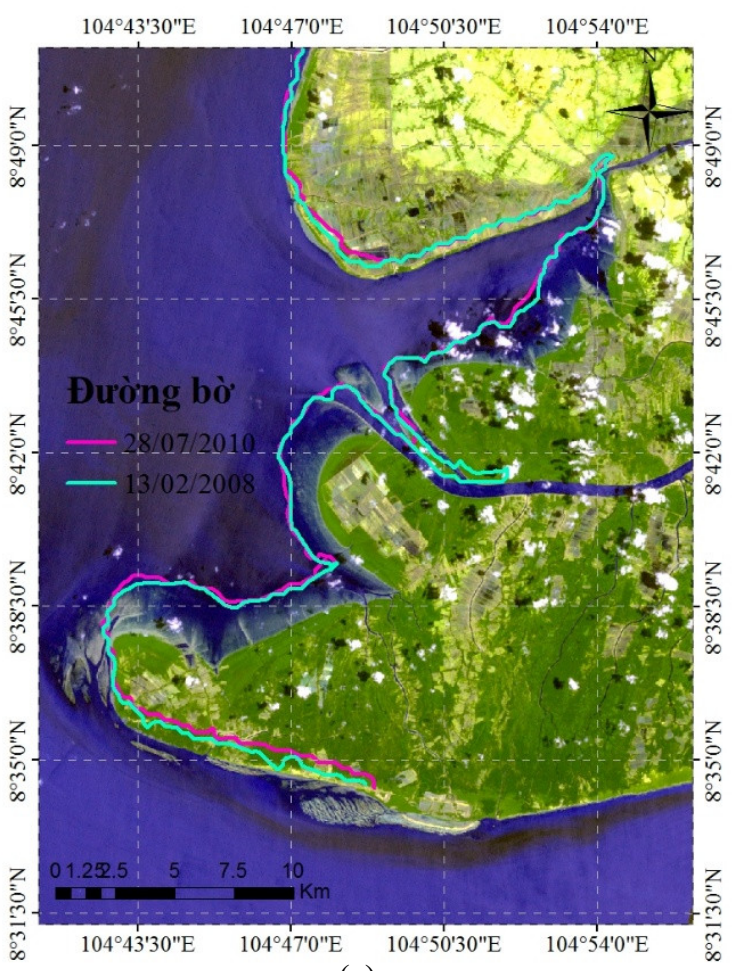

(a)

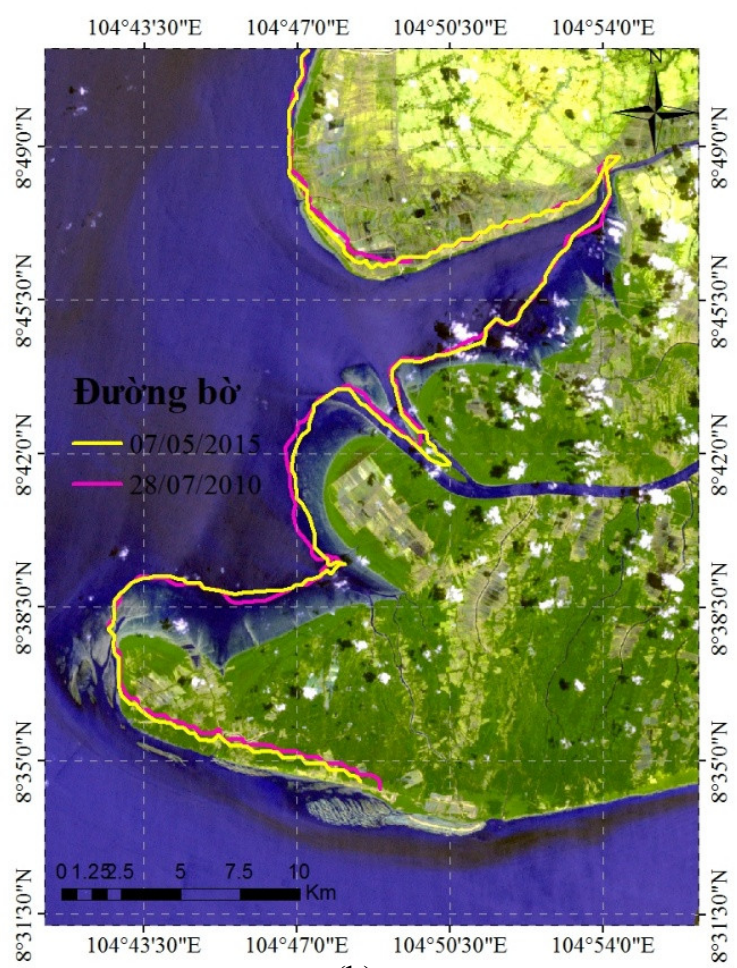

(b)

Hình 12. Biến động đường bờ vùng 4 (a) 2008-2010; (b) 2010-2015.

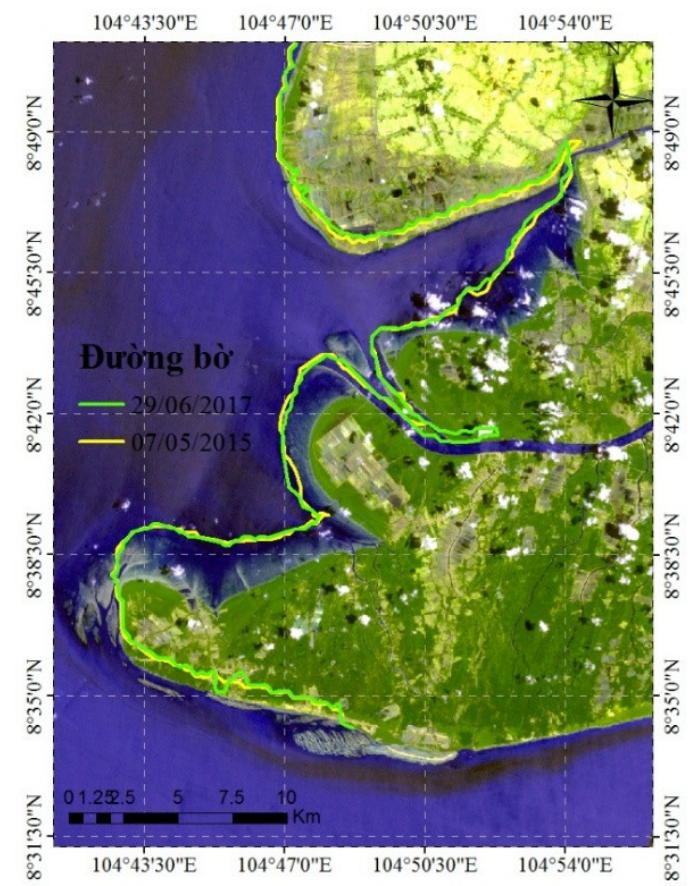

Hình 13. Biến động đường bờ vùng 4: 2015-2017.

\subsection{Biến động đường bờ vùng 5}

Vùng 5 là đoạn bờ biển từ huyện Cái Nước đến huyện U Minh. Đường bờ ở khu vực này ít thay đồi hơn so với 4 khu vực trước. Nhìn chung ta thấy quá trình xói lở và bồi tụ xảy ra xen kẽ nhau qua từng giai đoạn. Cụ thể, giai đoạn 1989-1998 hầu hết chỉ xảy ra quá trình xói lở đạt trung bình khoảng $25 \mathrm{~m} / \mathrm{năm}$, còn ở khu vực cửa sông Ông Đốc thì lại có xu hướng một 
Tạp chí Khí tượng Thủy văn 2021, 721, 66-79; doi:10.36335/VNJHM.2021(721).66-79

bên xói lở và môt bên bồi tụ (Hình 14a). Giai đoạn 1998-2001 quá trình bồi tụ lại chiếm ưu thế, đạt trung bình khoảng 45 m/năm (Hình 14b). Giai đoạn 2001-2004 (Hình 15a), 2004-2008 (Hình 15b), 2008-2010 (Hình 16a), 2010-2015 (Hình 16b), quá trình xói lở và bồi tụ xảy ra xen kẽ nhau qua từng giai đoạn, nhưng mức độ không đáng kể dao động trung bình khoảng 2-8 m/năm. Ở giai đoạn 2015-2017 thì hầu hết chỉ có quá trình xói lở xảy ra, với mức độ đạt trung bình khoảng 38 m/năm (Hình 17).

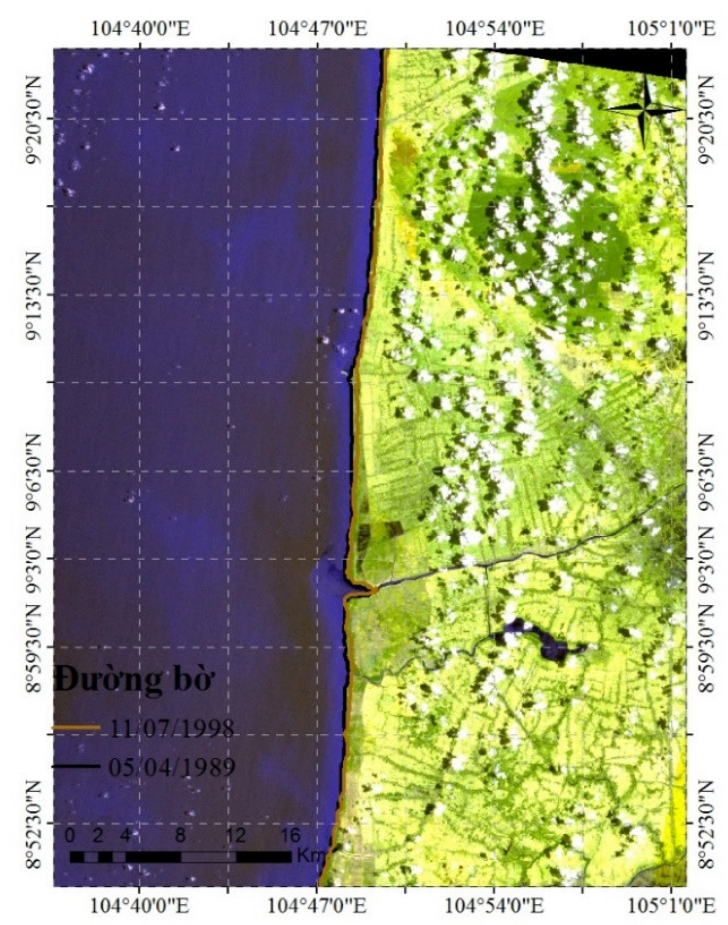

(a)

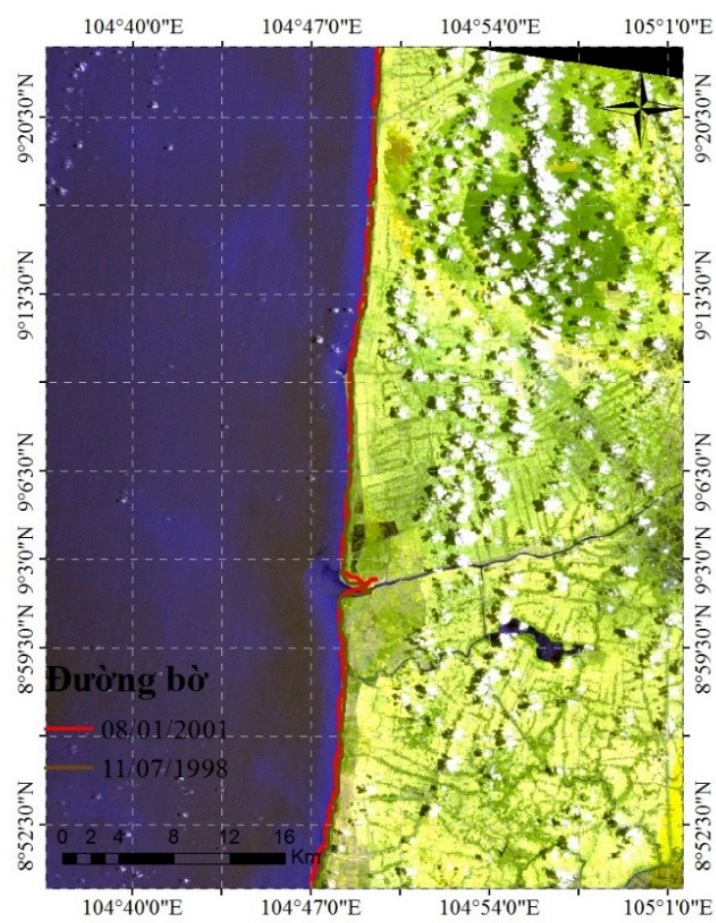

(b)

Hình 14. Biến động đường bờ vùng 5: (a) 1989-1998; (b) 1998-2001.

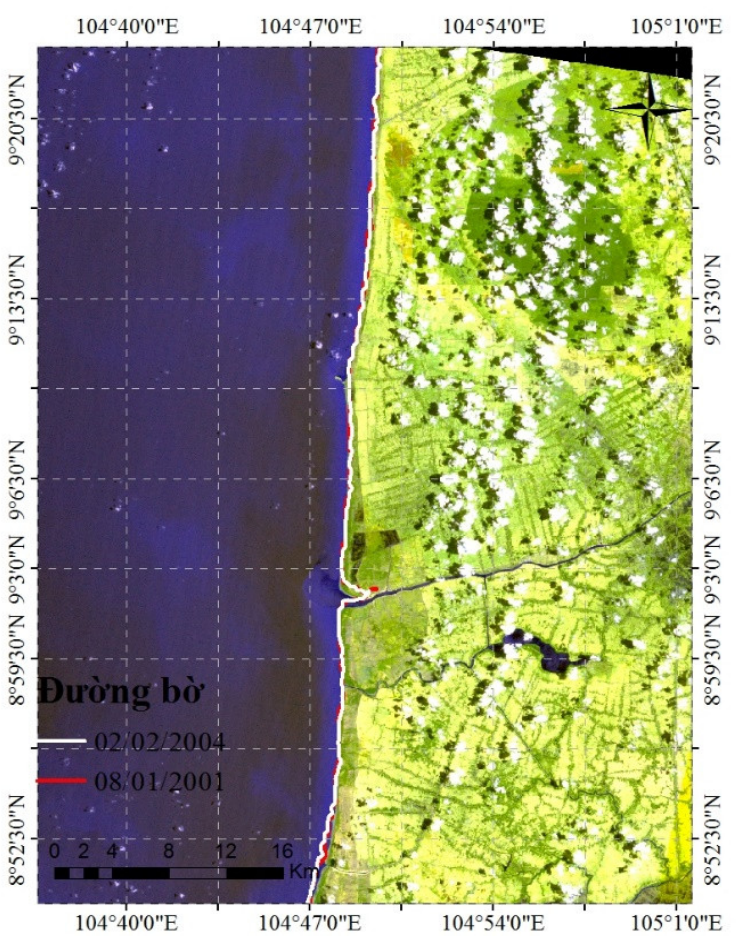

(a)

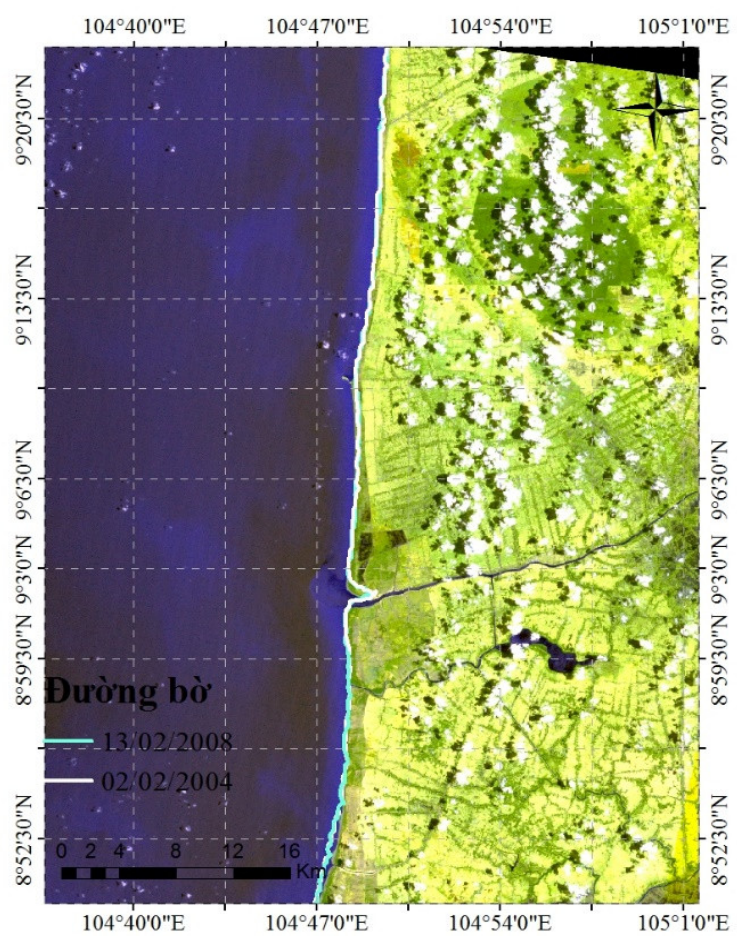

(b)

Hình 15. Biến động đường bờ vùng 5: (a) 2001-2004; (b) 2004-2008. 


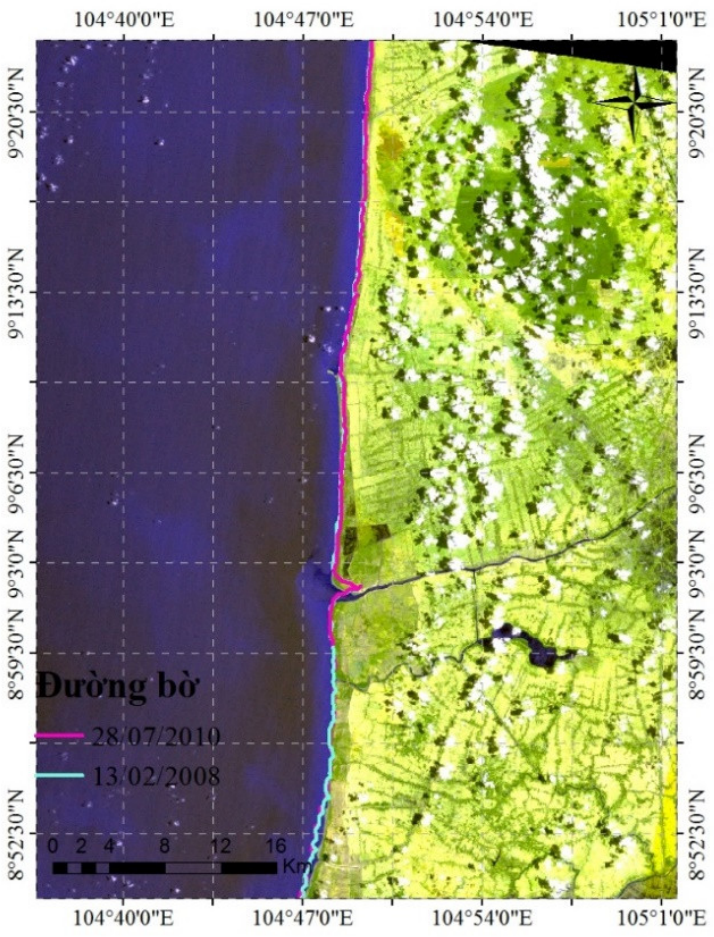

(a)

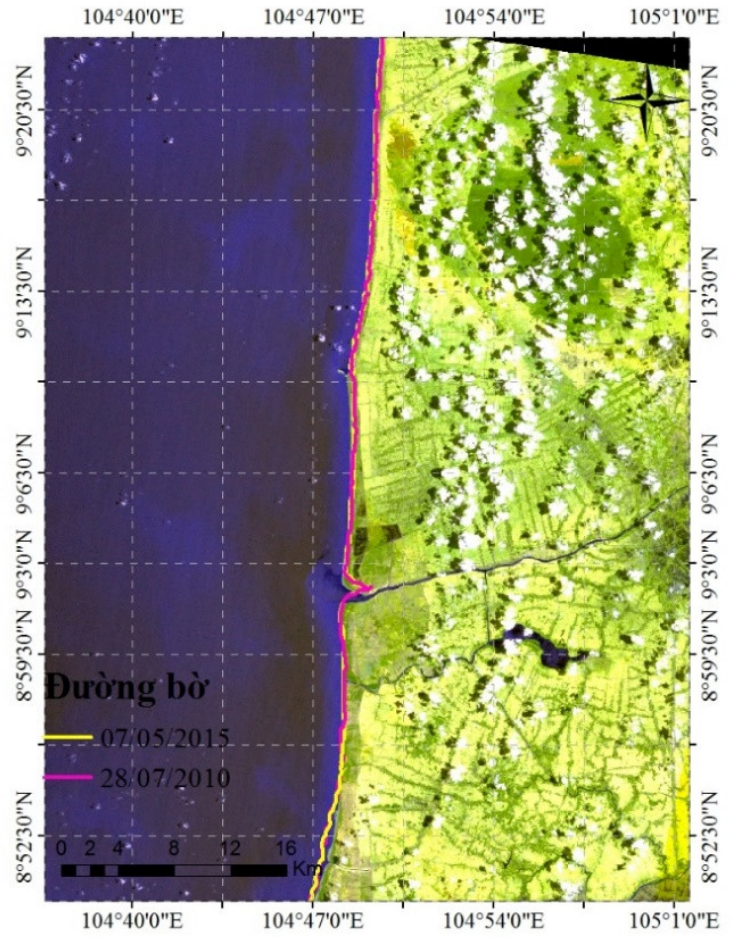

(b)

Hình 16. Biến động đường bờ vùng 5: (a) 2008-2010; (b) 2010-2015.

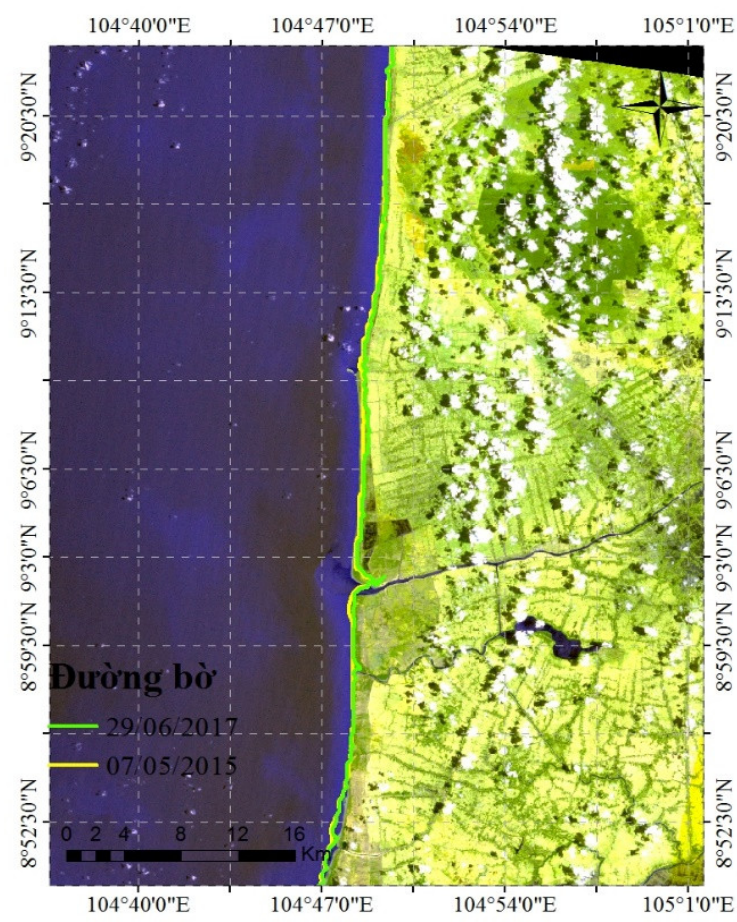

Hình 17. Biến động đường bờ vùng 5: 2015-2017.

\section{Kết luận}

Khu vực Đông Cà Mau, hầu hết chỉ có quá trình xói lở xảy ra từ năm 1989-2017, tuy nhiên ở khu vực phía gần mũi Cà Mau thì lại xảy ra quá trình bồi tụ, nhưng mức độ giảm dần qua các năm. Khu vực 2 bị xói lở nhiều nhất với tốc độ trung bình từ 1989-2017 đạt khoảng $31 \mathrm{~m} /$ năm và xói lở thấp nhất là ở khu vực 1 , trung bình đạt khoảng 14 m/năm. Ngoài ra, khu 
vực ở phía mũi Đông Cà Mau quá trình xói lở và bồi tụ xảy ra xen kẽ nhau qua các giai đoạn, nhưng xói lở vẫn chiếm ưu thế hơn. Đặc biệt, ta còn thấy quá trình xói lở ở khu vực này vẫn tiếp tục trong tương lai.

Khu vực phía Tây Cà Mau, nhìn chung quá trình bồi tụ chiếm ưu thế hơn so với quá trình xói lở trong giai đoạn 1989-2015, tuy nhiên ở những năm trở lại đây 2015-2017 thì quá trình xói lở lại chiếm ưu thế hơn. Ở khu vực 4 trung bình bồi tụ trong giai đoạn từ 1989-2015 là khoảng 33 m/năm, ở giai đoạn 2015-2017 trung bình xói lở đạt khoảng 10 m/năm. Ở khu vực 5, giai đoạn 1989-1998 hầu như chỉ có quá trình xói lở xảy ra trung bình đạt $24 \mathrm{~m} / \mathrm{năm}$, tuy nhiên ở giai đoạn từ năm 1998-2015 thì quá trình xói lở và bồi tụ lại xảy ra xen kẽ nhau với mức độ tương đối thấp, ở giai đoạn 2015-2017 quá trình xói lở lại xảy ra khá mạnh mẽ, trung bình đạt khoảng $38 \mathrm{~m} /$ năm. Đặc biệt, ở khu vực 4 quá trình bồi tụ còn tiếp diễn trong tương lai, còn ở khu vực 5 thì lại có xu hướng xói lở và bồi tụ qua tường giai đoạn.

[11] đã xây dựng được bản đồ đường bờ năm 1995, 2000, 2005, 2010 bằng ảnh viễn thám, Kết quả, cho thấy quá trình xói lở xảy ra ở biển Đông tỉnh Cà Mau và Bạc Liêu và quá trình bồi tụ xảy ra ở vùng biển Tây Cà Mau. [12] chỉ ra ở phía Đông Cà Mau là khu vực chủ yếu xảy ra quá trình xói lở với tốc độ lớn nhất là 33-66 m/năm, còn ở phía bờ Tây tại mũi Cà Mau và vùng bờ biển tiếp giáp vịnh Thái Lan xảy ra hiện tượng bồi tụ với tốc độ bồi tụ lớn nhất tại Đất Mũi và cửa Bảy Hạp là 40-89 m/năm qua các năm 1979, 1989, 1997, 2012 bằng ảnh vệ tinh.

Đóng góp của tác giả: Xây dựng ý tưởng nghiên cứu: N.T.T.; Lựa chọn phương pháp nghiên cứu: N.T.T.; Xử lý số liệu: N.T.T.; Phân tích mẫu: N.T.T.; Lấy mẫu: N.T.T.; Viết bản thảo bài báo: N.T.T.; Chỉnh sửa bài báo: N.T.T.

Lời cảm ơn: Nghiên cứu được tài trợ bởi Trường Đại học Khoa học Tự nhiên, ĐHQG-H CM trong khuôn khổ Đề tài mã số T2019-11.

Lò̀i cam đoan: Tác giả cam đoan bài báo này là công trình nghiên cứu của tác giả, chưa được công bố ở đâu, không sao chép từ những nghiên cứu trước đây; không có sự tranh chấp lợi ích trong nhóm tác giả.

\section{Tài liệu tham khảo}

1. Lập, N.V.; Oanh, T.T.K. Đặc điểm trầm tích bãi triều và thay đổi đường bờ biển khu vực ven biển tỉnh Cà Mau, châu thổ sông Cửu Long. Tạp chí các Khoa học về Trái Đất 2011, 1-9.

2. Thư, H.T.; Khôi, Đ.N.; Lợi, P.T.; Hồng, N.V. Phân tích biến động đường bờ sông khu vực Thành phố Hồ Chí Minh giai đoạn 1989-2015. Tạp chí phát triển Khoa học \& Công nghệ: Chuyên san Khoa học Trái đất \& Môi truoòng 2018, 80-88.

3. Giri, C.; Long, J.; Abbas, S.; Mani Murali, R.; Qamer, F.M.; Pengra, B.; Thau, D. Distribution and dynamics of mangrove forests of South Asia. J. Environ. Manage. 2014, 1-11.

4. Barik, K.K.; Mitra, D.; Annadurai, R.; Tripathy, J.K.; Nanda, S., Geospatial analysis of coastal environment: A case study on Bhitarkanika Mangroves, East coast of India. Indian J. Geo-Marine Sci. 2016, 45, 492-498.

5. Islam, M.M. Tracing mangrove forest dynamics of Bangladesh using historical Landsat data. Master Thesis, Physical Geography and Ecosystem Analysis, 2017.

6. Thinh, N.A.; Hens, L. A digital shoreline analysis system (DSAS) applied on mangrove shoreline changes along the Giao Thuy Coastal area (Nam Dinh, Vietnam) during 2005 - 2014. VN J. Earth Sci. 2017, 39, 87-96.

7. Hạo, L.V., Nghiên cứu biến động và xu thế diễn biến đường bờ tỉnh Kiên Giang sử dụng tư liệu viễn thám và mô hình. Luận văn thạc sĩ khoa học Trường Đại học Khoa học Tự nhiên Tp. Hồ Chí Minh, 2016. 
8. Vân, T.T.; Ánh, T.T.X.; Hồng, P.N.; Farid, D.G.; Nico, K. Application of remote sensing and GIS for detection of long-term mangrove shoreline changes in Mui Ca Mau, Vietnam. Biogeosci. 2014, 11, 3781-3795.

9. Đạt, K.T.; Quang, L.T.; Vương, N.B.; Toại, P.M. Thực trạng và giải pháp phát triển bền vững rừng phòng hộ ven biển tỉnh Bạc Liêu. Tạp chí Khoa Học Lâm Nghiệp 2017, 140-151.

10. Thieler, E.R.; Martine, D.; Ergul, A. The digital shoreline analysis system (DSAS) Version 4.0. - An arcGIS extension for calculating shoreline change, USGS, Open File Report 2008-1278, 2009.

11. Diễm, P.K.; Minh, V.Q.; Điệp, N.T.H.; Đen, Đ.V. Đánh giá tình hình sậ lở, bồi tụ khu vực ven biển tỉnh Cà Mau và Bạc Liêu từ 1995 - 2010 sử dụng viễn thám và công nghệ GIS. Tạp chí Khoa học Trường Đại học Cần Tho 2013, 35-43.

12. Phong, D.H.; Thục, T.; Hà, L.P.; Anh, N.N. Phân tích biến động đường bờ khu vực Cà Mau bằng ảnh Landsat. Hội thảo khoa học Quốc gia về Khí tượng Thủy văn, Môi trường và Biến đổi khí hậu lần thứ XVI, 2013, 270-275.

\title{
Analysis and evaluation of erosion and deposition processes in $\mathrm{Ca}$ Mau by remote sensing and GIS
}

\section{Nguyen Tien Thanh ${ }^{1}$ \\ ${ }^{1}$ Faculty of Physics and Engineering Physics, VNUHCM-University of Science; ntthanh@hcmus.edu.vn}

\begin{abstract}
Shoreline extraction using remote sensing and GIS technology is essential to assess shoreline changes quickly and promptly. $\mathrm{Ca}$ Mau is an area with 3 sides bordering the sea, so there is always an erosion and deposition process that occurs strongly. The study used remote sensing and GIS images to map shoreline changes in the Ca Mau area. The results showed that the shoreline in the Ca Mau area was quite complicated. Specifically, in the area in the East of Ca Mau from Dam Doi to Ngoc Hien, most of the erosion process occurred from 1989-2017, However, the deposition process occurs at the tip of Ca Mau. In the western of $\mathrm{Ca}$ Mau from $\mathrm{Ca}$ Mau cape to $\mathrm{U}$ Minh district, the deposition process prevailed in the period 1989-2015 but in the period from 2015-2017, the process of erosion. This is one of useful information for local authorities to have solutions for coastal area planning and management.
\end{abstract}

Keywords: Shoreline extraction; GIS; Erosion; Deposition; Ca Mau. 